Jurnal Bidan Cerdas
e-ISSN: 2654-9352 dan p-ISSN: 2715-9965
Volume 3 Nomor 2, 2021
DOI: $10.33860 /$ jbc.v3i2.418
Website: http://jurnal.poltekkespalu.ac.id/JBC
Penerbit: Poltekks Kemenkes Palu

\title{
Status Gizi dan Pemberian Kapsul Vitamin A Sebagai Faktor Risiko Pneumonia Balita Usia 18-59 Bulan
}

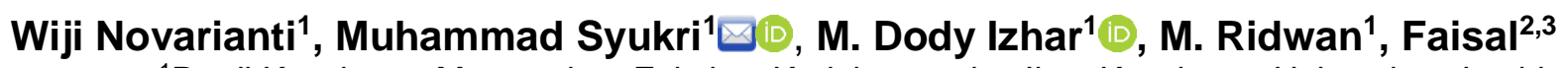 \\ ${ }^{1}$ Prodi Kesehatan Masyarakat, Fakultas Kedokteran dan Ilmu Kesehatan Universitas Jambi. \\ ${ }^{2}$ Prodi Doktor Epidemiologi, Fakultas Kesehatan Masyarakat, Universitas Indonesia. \\ ${ }^{3}$ Prodi Kesehatan Masyarakat, Fakultas Kesehatan, Universitas Patria Artha.
}

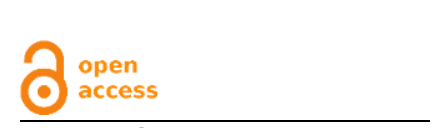

ARTICLE INFO

Article History:

Received: 2021-04-20

Accepted: 2021-05-25

Published: 2021-06-12

\author{
Kata Kunci: \\ Status gizi; \\ Vitamin A; \\ Imunisasi lengkap; \\ pneumonia; \\ balita;
}

\section{Keywords: \\ Nutritional status; \\ Vitamin A; \\ Complete \\ Immunization; \\ Pneumonia; \\ Under-five children;}

Email korespondensi: syukri.muhammad@unja.ac.id

\begin{abstract}
ABSTRAK
Pendahuluan: Pneumonia menyumbang 16\% penyebab kematian pada balita di dunia. Penelitian ini bertujuan untuk mengetahui status gizi, pemberian kapsul vitamin $\mathrm{A}$, dan imunisasi lengkap sebagai faktor risiko pneumonia pada balita usia 18-59 bulan. Metode: Penelitian ini menggunakan rancangan case-control dengan 47 balita kasus dan 47 balita kontrol. Kasus adalah balita dengan pneumonia berusia 18-59 bulan yang tercatat direkam medik Puskesmas Paal V Kota Jambi. Kontrol adalah balita yang tidak mengalami pneumonia dengan usia (rentang $\leq 3$ bulan), jenis kelamin, dan berasal dari kelurahan yang samadengan balita kasus. Pengambilan sampel dilakukan dengan teknik purposive dengan memilih data rekam medis pasien terbaru. Pengumpulan data dilakukan dengan metode wawancara pada Oktober-November 2020. Analisis data dilakukan secara univariat dan bivariat menggunakan uji Chi-Square. Hasil: Hasil penelitian menunjukkan status gizi $(p=0,023 \mathrm{OR}=3,93 \mathrm{Cl} 95 \%$ $1,29-11,96)$, pemberian kapsul Vitamin $A(p=0,026$ OR=3,12 Cl 95\% 1,237,91 ) merupakan faktor risiko kejadian pneumonia pada balita. Imunisasi lengkap bukanlah faktor risiko pneumonia pada balita. Kesimpulan penelitian adalah status gizi dan pemberian Vitamin A sebagai faktor risiko pneumonia pada balita usia 18-59 bulan.
\end{abstract}

ABSTRACT
Introduction: Pneumonia accounts for $16 \%$ of the causes of death in
children under five including Indonesia. This study aims to determine
nutritional status, provide vitamin A capsules, and complete immunization
as risk factors for pneumonia in toddlers aged $18-59$ months. Methods:
This study used a case-control design with 47 cases and 47 control
children. The case was a toddler with pneumonia aged $18-59$ months who
was registered at Puskesmas Paal V Jambi City. Controls were toddlers
who did not experience pneumonia with age (range $\leq 3$ months), gender,
and came from the same sub-district as the case toddler. Sampling was
done by purposive technique by selecting the latest patient medical record
data. Data collection was carried out by interview method in October-
November 2020. Data analysis was carried out univariate and bivariate
using the Chi-Square test. Results: The results showed nutritional status
(p=0.023 OR=3.93 95\% Cl 1.29-11.96), Vitamin A capsules administration
(p=0.026 OR=3.12 95\% Cl 1.23-7.91) is a risk factor for pneumonia in
children under-five. Complete immunization is nor a risk factor for
pneumonia in children under five. Conclusion: The conclusion of the study
was nutritional status and vitamin A administration as risk factors for
pneumonia in children aged 18-59 months.




\section{PENDAHULUAN}

Pneumonia adalah infeksi pernapasan akut yang umumnya disebabkan bakteri, virus, dan jamur yang menyebabkan peradangan kantung udara di paru-paru (alveoli) dan jaringan di sekitarnya (Dadonaite \& Roser, 2019; Katz \& Williams, 2018; UNICEF, 2016a). Alveoli akan terisi nanah atau cairan yang menyebabkan kesulitan bernafas, rasa sakit saat bernafas, kekurangan asupan oksigen sehingga berisiko tinggi untuk mengalami kematian pada balita (Dadonaite \& Roser, 2019; UNICEF, 2016a). Pneumonia merupakan penyebab terbesar kematian pada anak di dunia. Data WHO menunjukkan pneumonia menyebabkan 1,4 juta balita meninggal setiap tahunnya. Diperkirakan dari keseluruhan total kematian balita di dunia, 16 persen kematian disebabkan pneumonia. Pneumonia paling umum terjadi di wilayah Asia Selatan dan Sub-Sahara Afrika (WHO, 2020).

Kasus pneumonia di Indonesia mengalami peningkatan. Laporan Riset Kesehatan Dasar (Riskedas) 2013 menunjukkan prevalensi pneumonia balita sebesar 1,8\% naik menjadi $2 \%$ pada 2018. Pneumonia juga menjadi penyebab ke 2 kematian balita di Indonesia (Kemenkes RI, 2019). Penemuan kasus pneumonia balita di Provinsi Jambi pada tahun 2015 hingga 2018 bersifat fluktuatif. Pada tahun 2015 penemuan kasus sebesar 21,19\%, mengalami kenaikan cukup drastis pada 2016 menjadi 51,14\%. Pada 2017 mengalami penurunan signifikan menjadi $17,0 \%$, kemudian mengalami kenaikan pada tahun berikutnya menjadi 39,94\% (Dinkes Provinsi Jambi, 2019). Sementara di Kota Jambi, berdasarkan data Dinas Kesehatan Kota Jambi prevalensi kasus pneumonia mengalami peningkatan dari 1,79\% pada 2016 menjadi 1,81\% pada 2017. Pada tahun berikutnya mengalami peningkatan $0,2 \%$ menjadi 1,83\% (Dinkes Kota Jambi, 2019).

Faktor risiko pneumonia dapat diklasifikasikan ke dalam faktor individu, perilaku, dan lingkungan. Faktor-faktor individu pada balita dapat meliputi umur anak, berat badan saat lahir yang rendah, status gizi, status imunisasi dan pemberian vitamin A (Dewi et al., 2020; Fadl et al., 2020; Nirmolia et al., 2018; Windi, Qona'ah, et al., 2021). Faktor pada perilaku dapat berhubungan dengan cara penanggulangan serta pencegahan penyakit pneumonia itu sendiri (Anaba et al., 2020). Faktor lingkungan seperti pencemaran pada udara di ruangan rumah, ventilasi pada rumah, kelembaban, dan kepadatan pada hunian pada rumah (Fadl et al., 2020; Nirmolia et al., 2018; Rahmiza et al., 2019; Windi, Efendi, et al., 2021; Yeimo, 2018).

Puskesmas Paal V merupakan puskemas di Kota Jambi dengan prevalensi kejadian pneumonia paling tinggi. Pada 2016 proporsi pneumonia sebesar 3,34\% mengalami penurunan $0,34 \%$ pada 2017 menjadi 3,0\%. Prevalensi kejadian mengalami peningkatan pada tahun berikutnya menjadi 3,62\%, lalu mengalami penurunan pada 2019 menjadi 3,22\% (Puskesmas Paal V, 2019). Berdasarkan survei awal diperoleh $66 \%$ penderita pneumonia pada kelompok usia 18-59 bulan. Proporsi balita dengan gizi kurang sebesar 2,1\%, cakupan pemberian vitamin $\mathrm{A}$ juga belum memenuhi target, dan cakupan imunisasi mengalami penurunan selama masa pandemi. Selain itu, masih adanya variasi hasil penelitian menyangkut variabel yang diteliti. Oleh karena itu, penelitian ini bertujuan untuk mengetahui status gizi, pemberian kapsul Vitamin A dan imunisasi lengkap sebagai faktor risiko pneumonia pada balita usia 18-59 bulan di wilayah Kerja Puskesmas Paal V Kota Jambi.

\section{METODE PENELITIAN}

Penelitian ini menggunakan rancangan case-control dilaksanakan di Puskesmas Paal V pada Oktober-November 2020. Sampel penelitian ini berjumlah 94 responden 
yang dihitung menggunakan rumus Lemeshow untuk desain case-control yang terbagi atas 47 orang sampel kasus dan 47 orang sampel kontrol. Kasus adalah balita dengan rentang usia 18-59 bulan yang didiagnosis dokter mengalami pneumonia yang tercatat di rekam medik Puskesmas Paal V Kota Jambi. Kontrol adalah balita yang tidak mengalami pneumonia yang tercatat dalam rekam medik dengan matching pada jenis kelamin, usia (rentang \pm 3 bulan), dan berasal dari kelurahan yang sama dengan kasus. Variabel yang diteliti adalah status gizi balita, pemberian kapsul vitamin A, dan kelengkapan imunisasi dasar. Status gizi balita termasuk dalam kategori kurang jika sebelum mengalami pneumonia berat badan anak <-2 SD, pemberian kapsul vitamin A tidak rutin jika $<2$ kali. Status imunisasi tidak lengkap jika tidak mendapatkan atau melewati salah satu jadwal pemberian imunisasi sesuai usia balita. Pengambilan sampel kasus dan kontrol menggunakan teknik purposive sampling. Pengumpulan data dilakukan dengan metode wawancara menggunakan kuesioner dan observasi buku Kesehatan Ibu dan Anak (KIA). Data berat badan balita, pemberian vitamin A dan kelengkapan imunisasi dasar diperoleh dari buku Kesehatan Ibu dan Anak (KIA). Pengukuran variabel status gizi berdasarkan Berat Badan/Umur (BB/U) mengacu pada Peraturan Menteri Kesehatan Nomor 2 Tahun 2020 tentang Standar Antropometri Anak. Lembar informed concent disebar sebagai lembar persetujuan peneliti dengan responden. Pengolahan data dilakukan secara univariat dan bivariat menggunakan uji chi square menggunakan perangkat lunak SPSS 16.0.

\section{HASIL PENELITIAN}

Penelitian ini dianalisis dan disajikan secara univariat dan bivariat. Hasil pengolahan data secara univariat (tabel. 1) menunjukkan distribusi usia ibu pada kelompok kasus dan kelompok kontrol terbanyak pada rentang usia yang sama yaitu 30-39 tahun (40,4\% pada kasus) dan (50,0\% pada kontrol). Distribusi tingkat pendidikan responden kelompok kasus didominasi oleh tamatan SMA/SLTA $(53,2 \%)$, hal yang sama juga terjadi pada kelompok kontrol yang didominasi oleh responden dengan tingkat pendidikan tamat SMA/SLTA (48,9\%). Masih terdapat responden pada kelompok kontrol yang tidak tamat SD/ tidak sekolah sebesar 2,1\%. Sedangkan pada kelompok kasus pendidikan terendah responden yaitu tamat SD (17,0\%), namun hanya sedikit $(6,4 \%)$ yang memiliki pendidikan pada perguruan tinggi. Mayoritas responden baik pada kelompok kasus dan kontrol berprofesi bekerja sebagai ibu rumah tangga secara berturut-turut sebesar $80,9 \%$ dan sebesar $89,4 \%$.

Tabel 1. Distribusi Karakteristik Umum Responden

\begin{tabular}{|c|c|c|c|c|c|c|}
\hline \multirow[b]{2}{*}{ Variabel } & \multicolumn{2}{|c|}{ Kasus } & \multicolumn{2}{|c|}{ Kontrol } & \multicolumn{2}{|c|}{ Total } \\
\hline & $(n=47)$ & $(\%)$ & $(n=47)$ & (\%) & $(n=94)$ & $(\%)$ \\
\hline Usia lbu & & & & & & \\
\hline $20-29$ & 16 & 34,0 & 12 & 25,5 & 28 & 28,8 \\
\hline $30-39$ & 19 & 40,4 & 28 & 59,6 & 47 & 50,0 \\
\hline$\geq 40$ & 12 & 25,5 & 7 & 14,9 & 19 & 20,2 \\
\hline Pendidikan Terakhir Ibu & & & & & & \\
\hline $\begin{array}{l}\text { Tidak Tamat SD/Tidak } \\
\text { Sekolah }\end{array}$ & 0 & 0,0 & 1 & 2,1 & 1 & 1,1 \\
\hline Tamat SD & 8 & 17,0 & 7 & 14,9 & 15 & 16,0 \\
\hline Tamat SMP/SLTP & 11 & 23,4 & 12 & 25,5 & 23 & 24,5 \\
\hline Tamat SMA/SLTA & 25 & 53,2 & 23 & 48,9 & 48 & 51,1 \\
\hline Perguruan Tinggi/Diploma & 3 & 6,4 & 4 & 8,5 & 7 & 7,4 \\
\hline
\end{tabular}




\begin{tabular}{lrrrrrr}
\hline & \multicolumn{2}{c}{ Kasus } & \multicolumn{2}{c}{ Kontrol } & \multicolumn{2}{c}{ Total } \\
\cline { 2 - 7 } Variabel & $(\mathbf{n}=\mathbf{4 7})$ & $(\%)$ & $(\mathbf{n}=\mathbf{4 7})$ & $(\%)$ & $(\mathbf{n}=\mathbf{9 4})$ & $(\%)$ \\
\hline Jenis pekerjaan ibu & & & & & & \\
Ibu rumah tangga & 38 & 80,9 & 42 & 89,4 & 80 & 85,1 \\
Pedagang/wiraswasta & 9 & 19,1 & 4 & 8,5 & 13 & 1,1 \\
Buruh & 0 & 0,0 & 1 & 1,1 & 1 & 13,8 \\
\hline
\end{tabular}

Sumber: Data primer, 2020

Analisis bivariat bertujuan untuk mengetahui hubungan status gizi balita, pemberian kapsul Vitamin A, dan kelengkapan imunisasi dasar dengan kejadian pneumonia balita usia 18-59 bulan. Analisis tersebut bertujuan untuk membuktikan variabel yang diteliti apakah terbukti merupakan faktor risiko kejadian pneumonia pada balita.

Tabel 2. Hubungan Status Gizi, Kelengkapan Vitamin A, dan Kelengkapan Imunisasi Dasar dengan Pneumonia pada Balita di Wilayah KERJA Puskesmas Paal V Kota Jambi Tahun 2020

\begin{tabular}{|c|c|c|c|c|c|c|c|c|}
\hline \multirow{3}{*}{ Variabel } & \multicolumn{4}{|c|}{ Kejadian Pnemonia } & \multirow{2}{*}{\multicolumn{2}{|c|}{ Total }} & \multirow{3}{*}{$\begin{array}{c}P- \\
\text { value }\end{array}$} & \multirow{3}{*}{$\begin{array}{c}\text { OR } \\
(95 \% \mathrm{Cl})\end{array}$} \\
\hline & \multicolumn{2}{|c|}{ Kasus } & \multicolumn{2}{|l|}{ Kontrol } & & & & \\
\hline & $(n=47)$ & $(\%)$ & $(n=47)$ & $(\%)$ & $(n=94)$ & $(\%)$ & & \\
\hline \multicolumn{9}{|l|}{ Status gizi balita } \\
\hline Gizi kurang & 15 & 31,9 & 5 & 10,6 & 20 & 21,3 & \multirow[t]{2}{*}{0,023} & 3,93 \\
\hline Gizi baik & 32 & 68,1 & 42 & 89,4 & 74 & 78,7 & & $(1,2-11,9)$ \\
\hline \multicolumn{9}{|c|}{ Pemberian kapsul Vit A } \\
\hline Tidak rutin & 20 & 42,6 & 9 & 19,1 & 29 & 30,9 & \multirow[t]{3}{*}{0,026} & \multirow{3}{*}{$\begin{array}{c}3,12 \\
(1,2-7,9)\end{array}$} \\
\hline Rutin & 27 & 57,4 & 38 & 80,9 & 65 & 69,1 & & \\
\hline \multicolumn{7}{|l|}{ Kelengkapan } & & \\
\hline \multicolumn{9}{|l|}{ Imunisasi Dasar } \\
\hline Tidak lengkap & 19 & 40,4 & 26 & 55,3 & 45 & 47,9 & \multirow[t]{2}{*}{0,215} & \multirow{2}{*}{$\begin{array}{c}0,54 \\
(0,2-1,2)\end{array}$} \\
\hline Lengkap & 28 & 59,6 & 21 & 44,7 & 49 & 52,1 & & \\
\hline
\end{tabular}

Sumber: Data primer, 2020

Hasil analisis (tabel 2) menunjukkan variabel yang berhubungan dengan kejadian pneumonia pada balita usia 18-59 bulan yaitu status gizi balita $(p=0,023)$ dan pemberian kapsul vitamin $A(p=0,026)$. Sedangkan kelengkapan imunisasi dasar $(p=0,215)$ tidak memiliki hubungan yang signifikan terhadap pneumonia pada bayi dan terbukti bukan merupakan faktor risiko dalam penelitian ini. Adapun variabel penelitian yang terbukti merupakan faktor risiko terhadap pneumonia pada bayi usia 18-59 bulan yaitu status gizi balita dengan hasil $\mathrm{OR}=3,93$ pada $95 \% \mathrm{Cl}=1,29-11,96$. Variabel pemberian kapsul vitamin A juga terbukti merupakan faktor risiko dengan hasil $\mathrm{OR}=3,12$ pada $95 \% \mathrm{Cl}=1,23-7,91$.

\section{PEMBAHASAN}

Studi ini menemukan risiko pneumonia didapatkan lebih tinggi pada balita dengan status gizi kurang. Balita dengan status gizi kurang menyebabkan gangguan pertumbuhan, fungsi dan struktur otak, produksi tenaga, perilaku, hingga daya tahan tubuh. Daya tahan tubuh dan sistem imunitas akan berkurang menyebabkan balita mudah terserang penyakit infeksi seperti infeksi saluran pernapasan (Almaitser, 2009). Balita merupakan kelompok umur yang paling rentan mengalami penyakit infeksi karena sistem imun yang belum terbentuk sempurna. Hal tersebut akan semakin parah pada balita dengan konsumsi makanan yang kurang atau mengalami status gizi yang 
tidak baik (Ruwandasari, 2019). Status gizi dan infeksi akan saling berinteraksi dengan hubungan timbal balik, yaitu balita gizi buruk berisiko mengalami infeksi, dan infeksi berulang bisa menyebabkan status gizi balita menjadi buruk (Walson \& Berkley, 2018). Penyakit infeksi akan menghambat reaksi pada imunologi seseorang dengan cara menghabiskan sumber energi yang ada ditubuh (Farhadi \& Ovchinnikov, 2018; Gwela et al., 2019). Pada penelitian ini, beberapa responden mengatakan bahwa anaknya mengalami status gizi kurang dikarenakan nafsu makan menurun sehingga anak cenderung memilih mengkonsumsi makanan dengan kandungan gula dan Mono Sodium Glutamat (MSG) yang tinggi. Kondisi ini berlangsung beberapa minggu sehingga berat badan anak mengalami penurunan yang cukup drastis yang menyebabkan status gizi anak menjadi kurang baik. Balita dengan status gizi kurang memiliki risiko 3,93 kali untuk mengalami pneumonia dibanding balita dengan gizi baik. Hasil penelitian ini memperkuat hasil studi Frini, dkk (2018) di Wilayah Kerja Puskesmas Kamonji Kota Palu dimana balita dengan status gizi kurang berisiko 3,85 kali untuk mengalami pneumonia dibanding balita dengan status gizi baik (Frini et al., 2018). Studi yang dilakukan Meilina (2017) di Wilayah Kerja Puskesmas Samatang Borang Palembang juga menemukan hal yang sama. Status gizi merupakan faktor risiko pneumonia pada balita dengan nilai $\mathrm{OR}=3,53$ yang berarti bahwa balita dengan status gizi kurang berisiko 3,53 kali mengalami pneumonia dibanding balita dengan status gizi baik (Meilina \& Yusnilasari, 2017).

Balita yang tidak diberikan kapsul Vitamin A secara rutin berisiko untuk mengalami pneumonia dibandingkan dengan balita yang diberikan kapsul Vitamin $A$ secara rutin. Hasil studi ini mendukung hasil penelitian lain yang menemukan pemberian vitamin A merupakan faktor risiko kejadian pneumonia pada balita (Dewi et al., 2020; Frini et al., 2018; Gultom \& Wulandari, 2020; Irma et al., 2018). Vitamin A adalah zat gizi esensial bagi manusia karena berperan dalam epitel saluran pencernaan dan saluran pernafasan serta kulit. Vitamin A sangat bermanfaat untuk proses fisiologis dalam tubuh secara normal, meningkatkan fungsi penglihatan, proses bertumbuhan sel, meningkatkan imunitas dan pertumbuhan, serta menjaga tubuh dari penyakit infeksi (Awasthi \& Awasthi, 2020). Vitamin A sangat perlu untuk proses perkembangan dan pertumbuhan anak. Kekurangan vitamin A pada balita menyebabkan balita itu sendiri berisiko besar mengalami kesakitan yang akan meningkatkan kesakitan dan kematian, sehingga balita mudah terserang penyakit infeksi seperti radang paru-paru (UNICEF, 2016b). Karena itu suplementasi kapsul vitamin A dosis tinggi dilakukan Indonesia setiap bulan Februari dan Agustus, dimaksudkan agar mencegah bayi dan balita tidak mengalami kesakitan dan kekurangan vitamin A (Surat Edaran Tentang Bulan Kapsul Vitamin A, 2016). Pada penelitian ini, umumnya orang tua tidak rutin memberikan vitamin A dikarenakan tidak tahu atau lupa jadwal pemberian kapsul vitamin A.

Studi ini menemukan imunisasi tidak lengkap bukan merupakan faktor risiko kejadian pneumonia pada balita. Hasil penelitian ini berbeda dengan hasil penelitian lain yang menunjukkan status merupakan faktor risiko pneumonia pada balita (Hemagiri et al., 2014; Nirmolia et al., 2018). Imunisasi sendiri merupakan kegiatan pemberian vaksinasi kedalam tubuh untuk memberikan kekebalan terhadap penyakit. Imunisasi bisa mencegah infeksi yang bisa menjadi pemicu terjadinya pneumonia, dan juga balita yang memanfaatkan imunisasi mengindikasikan orang tuanya lebih sadar dalam memanfaatkan pelayanan kesehatan yang ada. Selain itu, balita dengan imunisasi lengkap juga kemungkinan mendatangi petugas kesehatan lebih awal dibanding yang tidak yang mana bisa mencegah komplikasi lanjutan penyakit yang diderita balita (Hemagiri et al., 2014). Studi ini menemukan kelengkapan imunisasi 
dasar bukan merupakan faktor risiko pneumonia pada balita kemungkinan disebabkan faktor lain yang lebih dominan. Imunisasi dasar bukanlah faktor risiko satu-satunya terjadinya pneumonia pada balita. Imunisasi dasar yang diberikan pada balita tidak secara khusus mencegah terjadinya pneumonia. Beberapa vaksin yang disuntikkan hanya mencegah terjadinya komplikasi penyakit ke arah pneumonia, sebagai contoh campak (Lailla et al., 2020).

\section{SIMPULAN DAN SARAN}

Status gizi kurang dan tidak rutin memberikan vitamin A merupakan faktor risiko pneumonia pada balita. Imunisasi tidak lengkap bukan merupakan faktor risiko pneumonia pada balita. Disarankan kepada Puskesmas dan petugas kesehatan untuk meningkatkan pemantauan pertumbuhan balita di fasilitas kesehatan maupun posyandu dengan memberikan penyuluhan atau konseling mengenai kebutuhan gizi balita dan pentingnya pemberian vitamin A. Bagi orang tua yang memiliki balita agar memperhatikan pertumbuhan serta perkembangan gizi balita secara rutin dan menjadi keluarga yang sadar gizi, sehingga permasalahan gizi dapat di tanggulangi. Serta meningkatkan kesadaran akan pentingnva pemberian vitamin A pada balita guna untuk meningkatkan kekebalan tubuh balita dari berbagai penyakit infeksi.

\section{UCAPAN TERIMA KASIH}

Ucapan terimakasih disampaikan kepada Dinas Kesehatan Kota Jambi yang telah memberikan ijin penelitian ini dan Kepala Puskesmas Paal IV beserta staff membantu dan memberikan motivasi sehingga penelitian ini terlaksana dengan baik.

\section{DAFTAR PUSTAKA}

Almaitser, S. (2009). Prinsip Dasar IImu Gizi. Jakarta. PT. Gramedia Pustaka Utama.

Anaba, U., Hutchinson, P. L., Abegunde, D., \& White Johansson, E. (2020). Pneumoniarelated ideations, care-seeking, and treatment behaviors among children under 2 years with pneumonia symptoms in northwestern Nigeria. Pediatric Pulmonology, 55(S1), S91S103. https://doi.org/10.1002/ppul.24644

Awasthi, S., \& Awasthi, A. (2020). Role of vitamin a in child health and nutrition. Clinical Epidemiology and Global Health, 8(4), 1039-1042. https://doi.org/10.1016/j.cegh.2020.03.016

Dadonaite, B., \& Roser, M. (2019). Pneumonia. Oxford Martin School and University of Oxford. https://ourworldindata.org/pneumonia

Dewi, I., Setiyawati, N., \& Estiwidani, D. (2020). Factors affecting pneumonia among children under five years old. Jurnal Kesehatan Ibu Dan Anak, 13 (2 SE-Research Articles). https://doi.org/10.29238/kia.v13i2.380

Dinkes Kota Jambi. (2019). Profil Kesehatan Kota Jambi.

Dinkes Provinsi Jambi. (2019). Profil Kesehatan Provinsi Jambi 2019.

Fadl, N., Ashour, A., \& Yousry Muhammad, Y. (2020). Pneumonia among under-five children in Alexandria, Egypt: a case-control study. Journal of the Egyptian Public Health Association, 95(1). https://doi.org/10.1186/s42506-020-00043-0

Farhadi, S., \& Ovchinnikov, R. (2018). The relationship between nutrition and infectious diseases: A review. Biomedical and Biotechnology Research Journal (BBRJ), 2(3), 168172. https://doi.org/10.4103/bbrj.bbrj_69_18

Frini, M., Rahman, N., \& Herman. (2018). Faktor Risiko Kejadian Pneumonia pada Balita di Wilayah Kerja Puskesmas Kamonji Kota Palu. Preventif: Jurnal Kesehatan Masyarakat, 9(1), 34-37. http://jurnal.untad.ac.id/jurnal/index.php/Preventif/article/view/10381 
Gultom, M., \& Wulandari, R. A. (2020). Relationship Between Vitamin A Deficiency and Pneumonia Incidence in Children. The 7th International Conference on Public Health, 434, 86-89. https://doi.org/https://doi.org/10.26911/the7thicph-FP.03.17

Gwela, A., Mupere, E., Berkley, J. A., \& Lancioni, C. (2019). Undernutrition, Host Immunity and Vulnerability to Infection Among Young Children. Pediatric Infectious Disease Journal, 38(8), e175-e177. https://doi.org/10.1097/INF.0000000000002363

Hemagiri, K., Sameena, A. R. B., Aravind, K., Khan, W., \& Sc, V. (2014). Risk factors for severe pneumonia in under five children: A hospital based study. International Journal of Research in Health Science, 2(1), 47-57. http://ijrhs.org/article/2014/2/1-5

Irma, R., Sunaryo, S., \& Toruntju, S. A. (2018). Pemberian Asi Ekslusif, Suplemen Vitamin A dan Asupan Seng dengan Risiko Kejadian Pneumonia Pada Anak Balita di Puskesmas Puuwatu Kecamatan Puuwatu Kota Kendari. Jurnal Kesehatan Manarang, 2(2), 105. https://doi.org/10.33490/jkm.v2i2.24

Katz, S. E., \& Williams, D. J. (2018). Pediatric Community-Acquired Pneumonia in the United States: Changing Epidemiology, Diagnostic and Therapeutic Challenges, and Areas for Future Research. In Infectious Disease Clinics of North America (Vol. 32, Issue 1, pp. 4763). W.B. Saunders. https://doi.org/10.1016/j.idc.2017.11.002

Surat Edaran tentang Bulan Kapsul Vitamin A, (2016). http://repo.stikesperintis.ac.id/1092/1/8 Kemenkes RI. (2019). Profil Kesehatan Indonesia Tahun 2019. In Kementrian Kesehatan Republik Indonesia. https://pusdatin.kemkes.go.id/resources/download/pusdatin/profilkesehatan-indonesia/Profil-Kesehatan-indonesia-2019.pdf

Lailla, Z. A., Andayani, H., Ismy, J., Bakhtiar, B., \& Liza, S. (2020). Hubungan Imunisasi Dasar Lengkap dengan Kejadian Pneumonia pada Balita di RS Zainoel Abidin Banda Aceh. Jurnal Kedokteran Nanggroe Medika, 3(1), 6-15. http://www.jknamed.com/jknamed/article/view/72

Meilina, S., \& Yusnilasari. (2017). The Correlation Between Nutritional Status, Birth Weight and Breastfeeding With Pneumonia Incidences of Under Five Years Child At Sematang Borang Community Health Center Palembang in 2016. International Conference on Disaster Management \& Infection Control, 1(1), 66-72. http://conference.stikepppnijabar.ac.id/index.php/icdmic/article/view/42

Nirmolia, N., Mahanta, T. G., Boruah, M., Rasaily, R., Kotoky, R. P., \& Bora, R. (2018). Prevalence and risk factors of pneumonia in under five children living in slums of Dibrugarh town. Clinical Epidemiology and Global Health, 6(1), 1-4. https://doi.org/10.1016/j.cegh.2017.07.004

Puskesmas Paal V. (2019). Profil Kesehatan Puskesmas Paal V.

Rahmiza, M., . S., \& . N. (2019). The Relationships Between Physical Environmental Conditions of House with Pneumonia Incidence on Children Under Five Years, in the Working Area of Ngesrep Health Centre, Semarang City. KnE Life Sciences, 4(10), 324. https://doi.org/10.18502/kls.v4i10.3802

Ruwandasari, N. (2019). Correlation Between Severe Malnutrition and Pneumonia Among Under-Five Children in East Java. Jurnal Berkala Epidemiologi, 7(2), 120. https://doi.org/10.20473/jbe.v7i22019.120-128

UNICEF. (2016a). One is too many: Ending child deaths from pneumonia and diarrhoea. https://data.unicef.org/wp-content/uploads/2016/11/UNICEF-Pneumonia-Diarrhoeareport2016-web-version_final.pdf

UNICEF. (2016b). Vitamin $\bar{A}$ supplements can save a child's life - Evidence for Action. https://blogs.unicef.org/evidence-for-action/vitamin-supplements-can-save-childs-life/

Walson, J. L., \& Berkley, J. A. (2018). The impact of malnutrition on childhood infections. In Current Opinion in Infectious Diseases (Vol. 31, Issue 3, pp. 231-236). Lippincott Williams and Wilkins.https:/doi.org/10.1097/QCO.0000000000000448

WHO. (2020). Pneumonia is the leading cause of death in children. https://www.who.int/maternal_child_adolescent/news_events/news/2011/pneumonia/en/

Windi, R., Efendi, F., Qona'ah, A., Adnani, Q. E. S., Ramadhan, K., \& Almutairi, W. M. (2021). Determinants of acute repiratory infection among children under-five years in Indonesia. Journal of Pediatric Nursing, xxxx. https://doi.org/10.1016/j.pedn.2021.03.010 
Windi, R., Qona'ah, A., Estiningtyas, Q., Adnani, S., Ramadhan, K., \& Almutairi, W. M. (2021). Determinants of acute repiratory infection among children under-five years in Indonesia. https://doi.org/10.1016/j.pedn.2021.03.010

Yeimo, Y. (2018). Environmental Factors Associated with Pneumonia in Children Under-Five in Nduga District, Papua. Journal of Epidemiology and Public Health, 3(3), 307-311. https://doi.org/10.26911/jepublichealth.2018.03.03.01 